\title{
Regulation of Intestinal Epithelial Calcium Transport Proteins by Stanniocalcin-1 in Caco2 Cells
}

\author{
Jinmei Xiang ${ }^{1,2,+}$, Rui Guo ${ }^{3,+}$, Chunyun Wan ${ }^{1,4,+}$, Liming Wu ${ }^{1}$, Shijin Yang ${ }^{1}$ and \\ Dingzong Guo ${ }^{1, *}$ \\ 1 College of Veterinary Medicine, Huazhong Agricultural University, Wuhan 430070, Hubei, China; \\ hbswkjxjm@163.com (J.X.); wanchunyun16@163.com (C.W.); hnzdwlm@163.com (L.W.); \\ hznydxysj@163.com (S.Y.) \\ 2 Department of Animal Science, Hubei Vocational College Of Bio-Technology, Wuhan 430070, Hubei, China \\ 3 Hubei Key Laboratory of Embryo and Molecular Breeding, Hubei Academy of Agricultural Sciences, \\ Wuhan 430064, Hubei, China; hbnkyguorui@163.com \\ 4 College of Animal Science, Yangtze University, Jingzhou 434023, Hubei, China \\ * Correspondence: hlgdz@163.com; Tel.: +86-27-8728-6009 \\ + These authors contributed equally to this study.
}

Academic Editors: ChulHee Kang and Hiroyuki Kobori

Received: 14 April 2016; Accepted: 29 June 2016; Published: 9 July 2016

\begin{abstract}
Stanniocalcin-1 (STC1) is a calcium and phosphate regulatory hormone. However, the exact molecular mechanisms underlying how STC1 affects $\mathrm{Ca}^{2+}$ uptake remain unclear. Here, the expression levels of the calcium transport proteins involved in transcellular transport in $\mathrm{Caco} 2$ cells were examined following over-expression or inhibition of STC1. These proteins include the transient receptor potential vanilloid members (TRPV) 5 and 6, the plasma membrane calcium ATPase $1 \mathrm{~b}$ (PMCA1b), the sodium/calcium exchanger (NCX1), and the vitamin D receptor (VDR). Both gene and protein expressions of TRPV5 and TRPV6 were attenuated in response to over-expression of STC1,

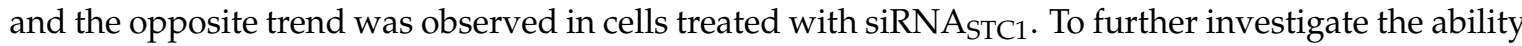
of STC1 to influence TRPV6 expression, cells were treated with $100 \mathrm{ng} / \mathrm{mL}$ of recombinant human STC1 (rhSTC1) for $4 \mathrm{~h}$ following pre-transfection with siRNA ${ }_{S T C 1}$ for $48 \mathrm{~h}$. Intriguingly, the increase in the expression of TRPV6 resulting from siRNASTC1 was reversed by rhSTC1. No significant effect of STC1 on the expression of PMCA1b, NCX1 or VDR was observed in this study. In conclusion, the effect of STC1 on calcium transport in intestinal epithelia is due to, at least in part, its negative regulation of the epithelial channels TRPV5/6 that mediate calcium influx.
\end{abstract}

Keywords: calcium; intestinal epithelium; stanniocalcin-1; TRPV5; TRPV6

\section{Introduction}

Calcium $\left(\mathrm{Ca}^{2+}\right)$ is an essential ion required for critical physiological processes in almost all organisms. Therefore, maintaining $\mathrm{Ca}^{2+}$ homeostasis is of vital importance. In mammals, $\mathrm{Ca}^{2+}$ is absorbed across intestinal or renal epithelia by two routes: a passive, non-saturable, poorly regulated paracellular process, and an active, saturable, highly regulated transcellular process [1]. The transcellular route requires energy and occurs predominantly in the proximal small intestine, renal distal convoluted tubules and the connecting tubules in response to $\mathrm{Ca}^{2+}$ demands [2]. In contrast, paracellular transport takes place throughout the length of the intestine and renal tubules, being responsible for the bulk of $\mathrm{Ca}^{2+}$ (re-)absorption in a concentration-dependent diffusion manner that does not consume energy [2].

Transcellular $\mathrm{Ca}^{2+}$ transport across intestinal or renal epithelia involves three steps. First, $\mathrm{Ca}^{2+}$ influx occurs at the apical membrane via epithelial $\mathrm{Ca}^{2+}$ channels (ECaC), which include the 
transient receptor potential vanilloid (TRPV) members 5 and 6 [1]. This step is considered to be the rate-limiting step for transcellular $\mathrm{Ca}^{2+}$ transport [1]; Second, intracellular diffusion is facilitated by vitamin $\mathrm{D}$-dependent $\mathrm{Ca}^{2+}$-binding proteins calbindin- $\mathrm{D}_{9 \mathrm{~K}}$ and calbindin- $\mathrm{D}_{28 \mathrm{~K}}$ [3]; Last, extrusion at the basolateral membrane is achieved by either the $\mathrm{Na}^{+} / \mathrm{Ca}^{2+}$ exchanger $N C X 1$ or the plasma membrane calcium ATPase (PMCA) 1b [4]. The entire process is regulated by 1,25-dihydroxyvitamin $\mathrm{D}\left[1,25(\mathrm{OH})_{2} \mathrm{D}_{3}\right]$, whose activity is mediated by a vitamin $\mathrm{D}$ receptor $(V D R)$ [5].

In mammals, TRPV6 is expressed in small intestine, kidney and exocrine tissues, while TRPV5 is predominantly expressed in kidney and human syncytiotrophoblasts [6]. Calbindin- $\mathrm{D}_{9 \mathrm{~K}}$ is present primarily in small intestines and kidneys (only mice), while calbindin- $\mathrm{D}_{28 \mathrm{~K}}$ is present in kidneys, bones and brain [1]. PMCA1b is the predominant isoform of PMCA and is abundantly expressed in small intestines and other tissues [7], while NCX1 is abundantly expressed in kidneys and at a low level in intestines [1]. These data indirectly suggest that transcellular $\mathrm{Ca}^{2+}$ transport across intestinal epithelia is predominantly mediated by TRPV6, calbindin- $\mathrm{D}_{9 \mathrm{~K}}$ and $P M C A 1 b$, whereas TRPV5, calbindin- $\mathrm{D}_{28 \mathrm{~K}}$ and NCX1 are the principal components underlying renal $\mathrm{Ca}^{2+}$ re-absorption in mammals.

In mammals, extra- and intracellular $\mathrm{Ca}^{2+}$ concentrations are modulated by a complex homeostatic system including the hormones $1,25(\mathrm{OH})_{2} \mathrm{D}_{3}$, parathyroid hormone $(\mathrm{PTH})$, and calcitonin [8]. However, stanniocalcin (STC) is considered as the main $\mathrm{Ca}^{2+} /$ inorganic phosphate (Pi)-regulating hormone in fish, preventing gill and intestinal $\mathrm{Ca}^{2+}$ transport and promoting renal Pi re-absorption [9]. STC1, the mammalian homolog of fish STC, is expressed in multiple tissues and organs of many species and is involved in a variety of biological and pathological processes $[10,11]$. In contrast to its fish counterpart, STC1 is not detected in the circulatory system under normal circumstances except during gestation and lactation [12]. However, the regulatory effects of STC1 on $\mathrm{Ca}^{2+} / \mathrm{Pi}$ homeostasis are conserved from fish to mammals [13]. The exact molecular mechanism underlying how STC1 affects $\mathrm{Ca}^{2+}$ uptake has not been fully characterized. The purpose of this study was therefore to observe the effects of STC1 on the proteins mediating $\mathrm{Ca}^{2+}$ entry and extrusion in the intestines, and elucidate the mechanism of STC1-induced inhibition of $\mathrm{Ca}^{2+}$-absorption.

\section{Results}

\subsection{Expression of STC1 in Transfected Caco2 Cells}

STC1 protein levels were detected by Western blotting. We found that the PIRES-STC1 vector was an effective vehicle for over-expressing STC1 protein and the expression was maintained at a high level after $48 \mathrm{~h}$ (Figure 1A). However, when cells were transfected with siRNASTC1 alone or with pIRES-STC1, STC1 protein expression was markedly blocked (Figure 2B).

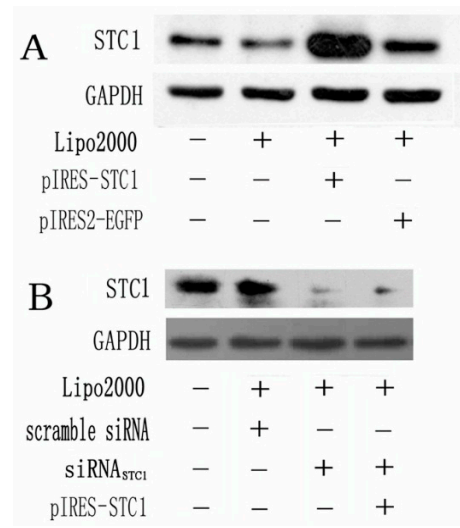

Figure 1. Detection of the expression of STC1 in Caco2 cells by Western blotting. (A) STC1 expression in Caco 2 cells was detected $48 \mathrm{~h}$ post transfection of pIRES-STC1; (B) STC1 expression was detected $48 \mathrm{~h}$

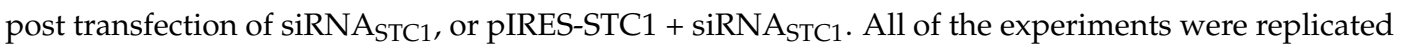
for three times. 


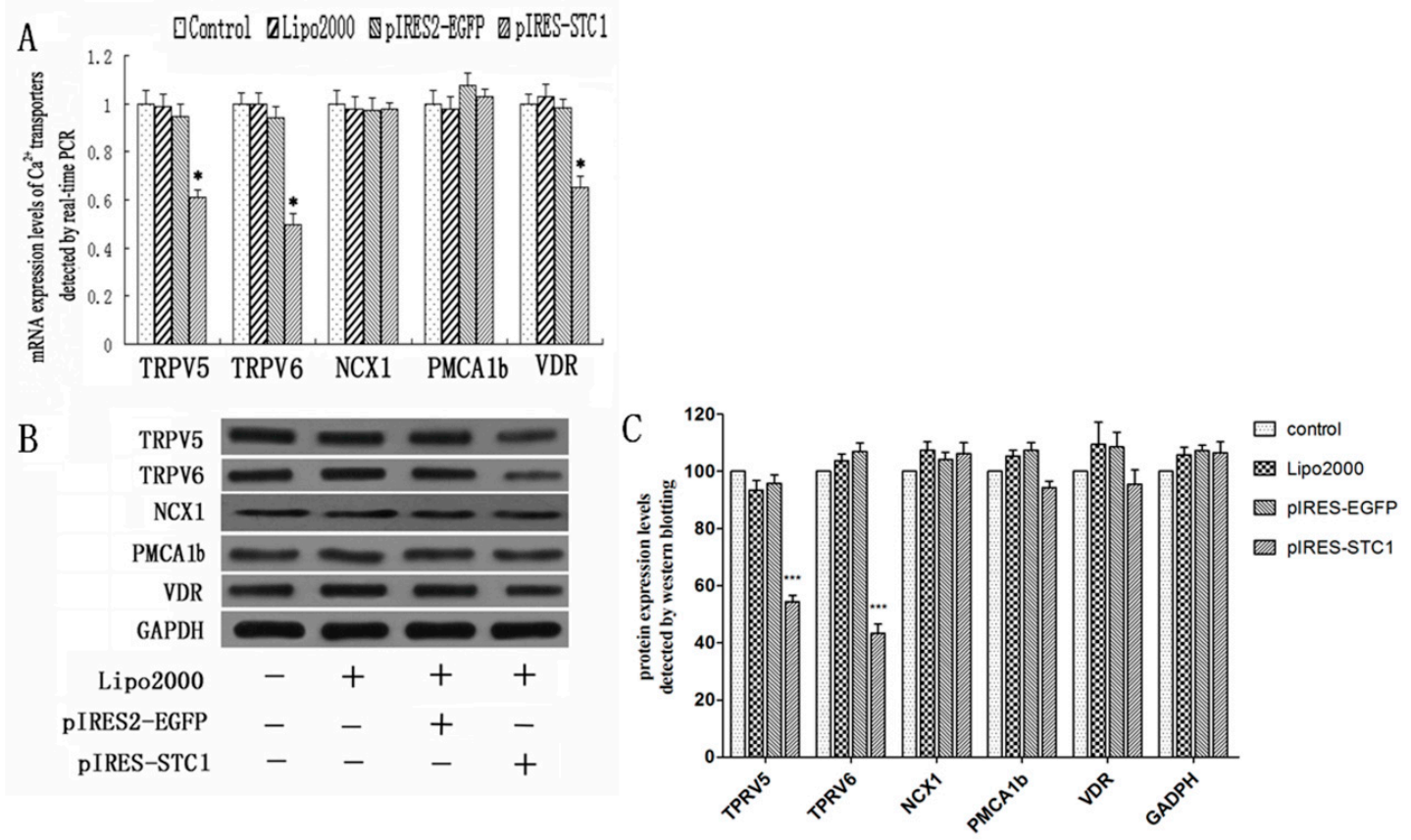

Figure 2. Analysis of transcellular calcium transport gene and protein expression levels in Caco2 cells transfected with pIRES-STC1. (A) Quantitative RT-PCR analysis of transcellular calcium transport genes $(n=4)$. Over-expression of STC1 reduced gene expression of TRPV5, TRPV6 and VDR, with no effects on the expression of NCX1 and PMCA1b genes (* $p<0.05$ compared with control); (B) Western blotting analysis of transcellular calcium transport proteins. TRPV5 and TRPV6 protein expression levels were down-regulated by the over-expression of STC1. NCX1, PMCA1b and VDR proteins levels were not affected. All the experiments were replicated for three times; (C) Densitometric quantification of the Western blotting shown in (B). Each bar represents the means \pm SD. $(n=3) .{ }^{* * *} p<0.001$ compared with control.

\subsection{Effect of STC1 on the Expression of Calcium-Transporting Proteins}

To determine the influence of STC1 over-expression on the regulation of $\mathrm{Ca}^{2+}$-transport proteins in Caco2 cells, cells were transfected with recombinant plasmid pIRES-STC1 for $48 \mathrm{~h}$ and subsequently analyzed. A marked decrease in the gene expression of TRPV5, TRPV 6 and VDR was identified by real-time RT-PCR in cells transfected with pIRES-STC1 when compared with control cells $(p<0.05$; Figure 2A). No significant changes in the gene expression of $M C A 1 b$ or NCX1 were detected. Similarly, an obvious decrease of TRPV5 and TRPV 6 expression was observed in pIRES-STC1 transfected cells (Figure 2B,C).

To further characterize the response of $\mathrm{Ca}^{2+}$-transport proteins to STC1 in Caco2 cells, we designed an siRNA sequence (siRNASTC1) to inhibit the STC1 synthesis. Figure 3A revealed that TRPV5, TRPV6 and VDR genes expression all significantly increased $(p<0.01) 48 \mathrm{~h}$ following siRNASTC1 transfection. Additionally, co-transfection of siRNASTC1 and pIRES-STC1 for $48 \mathrm{~h}$ also resulted in significant up-regulation of TRPV5 and TRPV6 genes expression $(p<0.01)$ (Figure 3A). Similar differences were not observed for PMCA1b, NCX1 and VDR genes expression following co-transfection of pIRES-STC1 and siRNA $A_{\text {STC1 }}$. Western blotting revealed a significant increase in the protein levels of TRPV5, $T R P V 6$ and $V D R$ in response to siRNA ${ }_{\mathrm{STC} 1}$ treatment alone (Figure 3B,C), when co-transfected with pIRES-STC1, the levels of TRPV5, TRPV6 and VDR were significantly decreased compared with siRNA $_{S T C 1}$ treatment alone (Figure 3B,C). However, these treatments had no effect on PMCA1b and NCX1 protein expression. 
A

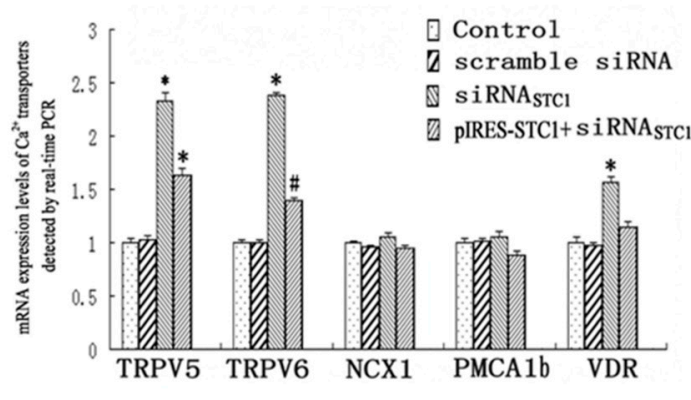

B
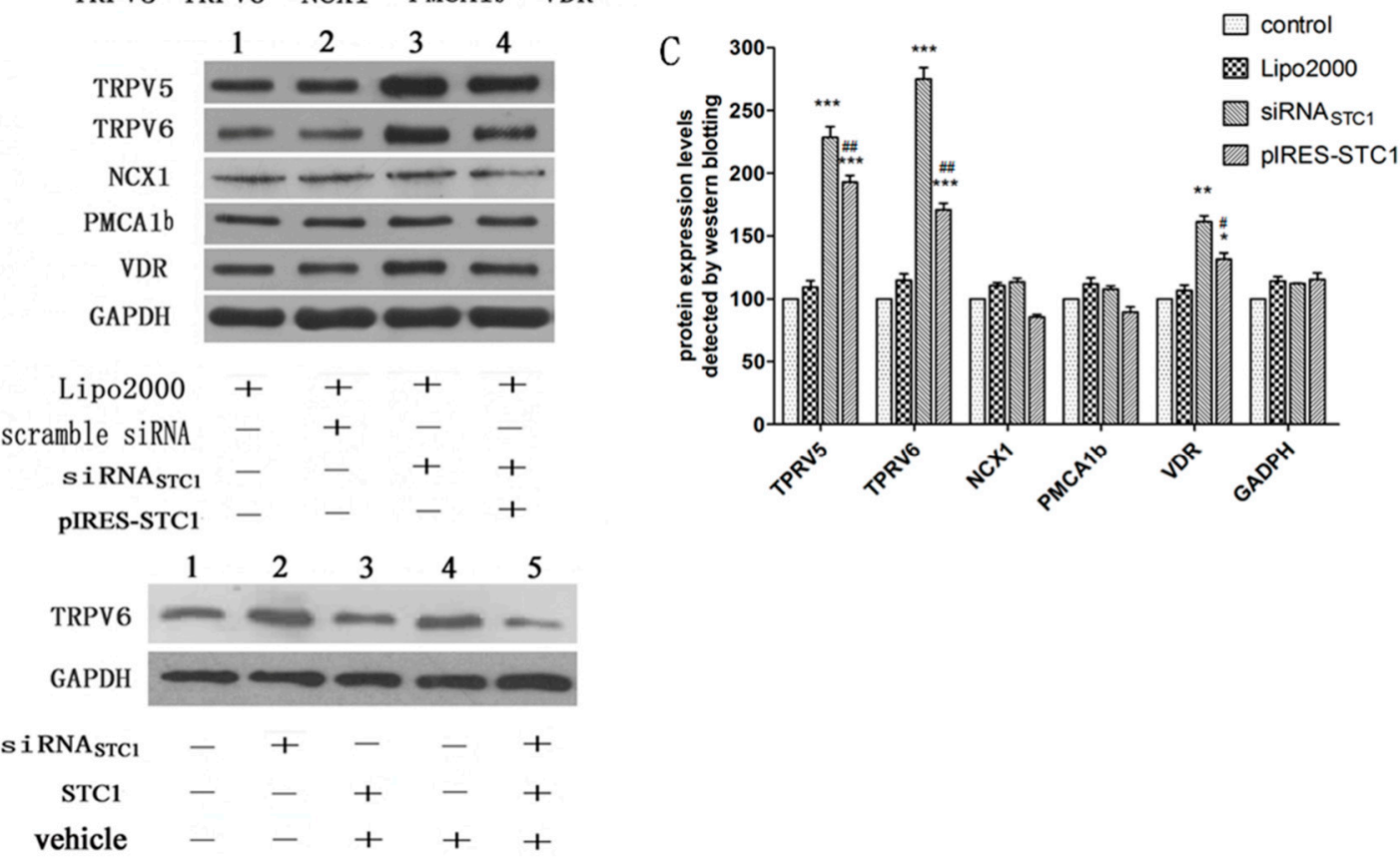

D

Figure 3. Analysis of epithelial $\mathrm{Ca}^{2+}$-transport protein expression in $\mathrm{Caco} 2$ cells after various treatments. $(\mathbf{A}, \mathbf{B})$ display quantitative PCR and western blotting analysis of the transport genes and proteins $(n=4)$. Both gene expression and protein levels of TRPV5, TRPV6 and VDR were enhanced following $48 \mathrm{~h}$ transfection with siRNA ${ }_{S T C 1}$, and also with $48 \mathrm{~h}$ co-transfection with siRNASTC1 and pIRES-STC1 (with the exception of $V D R$ ). Expression of NCX1 and PMCA1b revealed no significant change with inhibited expression of STC1 ( $\left.{ }^{*} p<0.01,{ }^{*} p<0.05\right)$; (C) Densitometric quantification of the Western blotting shown in (B). Each bar represents the means \pm SD. $(n=3)$. ${ }^{* * *} p<0.001,{ }^{* *} p<0.01,{ }^{*} p<0.05$ compared with control; ${ }^{\# \#} p<0.01,{ }^{\#} p<0.05$ compared with siRNASTC1 alone; (D) Western blotting analysis of TRPV6 protein expression. TRPV6 protein levels increased following transfection with siRNA $_{S T C 1}$, and slightly decreased after a $4 \mathrm{~h}$ treatment with $100 \mathrm{ng} / \mathrm{mL}$ rhSTC1. However, treatment

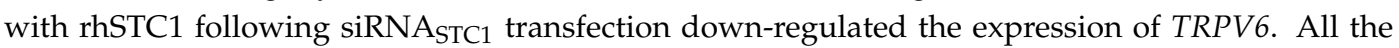
experiments were replicated for three times.

To complement the above findings, regulation of TRPV6 expression by STC1 was investigated in further detail. Pre-treating cells with siRNA $\mathrm{STC}_{\mathrm{T} 1}$ enhanced TRPV6 protein expression, while exposure to $100 \mathrm{ng} / \mathrm{mL}$ of rhSTC1 for $4 \mathrm{~h}$ did not down-regulate TRPV6 protein expression (Figure 3D). Intriguingly, cells exposed to $100 \mathrm{ng} / \mathrm{mL}$ rhSTC1 for $4 \mathrm{~h}$ following pre-treatment with siRNASTC1 for $48 \mathrm{~h}$ exhibited a marked attenuation of TRPV6 protein expression when compared with siRNASTC1 treatment.

\section{Discussion}

The functions of STC1 have been extensively studied for decades, but many of them remain to be elucidated [14]. Unlike in fish, where STC functions as an anti-hypercalcemic hormone in a classical endocrine fashion [15], mammalian STC1 is normally undetectable in the blood and ubiquitously 
distributed in several tissues [16]. This implies that STC1 acts primarily as a local mediator of cell function in a paracrine/autocrine fashion. The $\mathrm{Ca}^{2+} / \mathrm{Pi}$ regulatory function of STC1 appears to have been maintained in mammals, although it has been described as a multi-functional hormone that is unlikely to play important roles in systemic $\mathrm{Ca}^{2+} / \mathrm{Pi}$ homeostasis $[11,13,17,18]$. However, there is limited information available concerning the relationship between STC1 and novel epithelial $\mathrm{Ca}^{2+}$ channels or transporters in mammals. Therefore, this study aimed to investigate the precise effects of STC1 on these proteins.

The digestive organs are important locations where STC1 influences $\mathrm{Ca}^{2+} / \mathrm{Pi}$ transport. Madsen et al. identified STC1 as a novel regulatory protein that decreased $\mathrm{Ca}^{2+}$ absorption and stimulated Pi absorption in swine and rat duodenum [17], providing direct evidence for the role of mammalian STC1 in the intestine in vitro. Here, we have examined the effects of STC1 over-expression and silencing on the regulation of proteins involved with $\mathrm{Ca}^{2+}$ entry and extrusion. Caco2 cells were employed as they have been widely employed to study duodenal transport processes given their resemblance to adult differentiated intestinal cells [19]. We have identified that over-expression of STC1 inhibits gene and protein expression of the epithelial $\mathrm{Ca}^{2+}$ channels $T R P V 5 / 6$, particularly TRPV6, a principal mechanism of $\mathrm{Ca}^{2+}$ transport across intestinal epithelia. Furthermore, this inhibition could be removed by blocking STC1 expression via siRNA. Supporting this, exogenous rhSTC1 treatment abolished

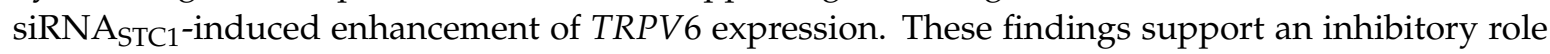
for STC1 on TRPV6 and 5 gene and/or protein expression, consistent with previous observations in zebrafish where $z \mathrm{ECaC}$ mRNA expression was enhanced following down-regulation of STC1 by morpholino microinjection [20], and in the human heart where STC1 functions as an L-channel blocker by mimicking the effect of nimodipine [21]. These data further support the hypothesis that ECaC form the primary hormone-regulated sites for active $\mathrm{Ca}^{2+}$ transepithelial transport in the intestine and renal tubules [1].

Consistent with previous findings obtained from work in fish [2,22], we did not observe changes to the levels of the transporters (PMCA1b and NCX1) that mediate $\mathrm{Ca}^{2+}$ efflux at the basolateral membrane, with changes to STC1 expression. Therefore, we speculate that STC1 does not affect ATP-dependent $\mathrm{Ca}^{2+}$-efflux, at least in intestinal cells. Additionally, given that it has been well established that $\mathrm{Na}^{+} / \mathrm{Ca}^{2+}$ exchange is not the major mechanism underlying $\mathrm{Ca}^{2+}$ efflux in enterocytes [23], the low impact of STC1 on NCX1 expression in Caco2 cells is not surprising. Furthermore, a previous report has shown that STC1 can be up-regulated by $1,25(\mathrm{OH})_{2} \mathrm{D}_{3}$ in opossum kidneys [24]. However, we found that STC1 over-expression resulted in a significant inhibition of VDR mRNA levels as detected by real-time RT-PCR, while further marked effects on the protein expression were not investigated by the methods we employed. These data suggest that STC1 does not affect the functions of $1,25(\mathrm{OH})_{2} \mathrm{D}_{3}$ in $\mathrm{Ca}^{2+}$ transport across the absorptive epithelia; however, whether STC1 alters the concentration of $1,25(\mathrm{OH})_{2} \mathrm{D}_{3}$ in local cells and its synthesis in other sites remains unclear.

\section{Materials and Methods}

\subsection{Cell Culture}

Caco2 cells (ATCC HTB-37) were maintained in a high-glucose formulation of Iscove's Modified Dulbecco's Medium (IMDM, Hyclone, Logan, UT, USA) supplemented with $10 \%$ fetal bovine serum (Hyclone), $50 \mathrm{mg} / \mathrm{mL}$ penicillin G (Sigma, St. Louis, MO, USA), $50 \mathrm{mg} / \mathrm{mL}$ streptomycin sulfate (Sigma), and $4 \mathrm{mM}$ glutamine (Sigma) and incubated at $37^{\circ} \mathrm{C}$ in a humidified atmosphere containing $5 \% \mathrm{CO}_{2}$. For experiments, cells were detached by $0.25 \%$ trypsin (Sigma) with $0.02 \%$ Ethylene Diamine Tetraacetic Acid (EDTA), seeded in six-well dishes (Nest Biotech, Shanghai, China) at a density of $2 \times 10^{5}$ cells/well, and fed every other day with growth medium for 1-2 weeks to achieve a fully differentiated and attached cell phenotype prior to experimental treatments. 


\subsection{Construction of STC1 Expression Vector}

Total RNA from Caco2 was isolated using TRIzol reagent (Invitrogen, Carlsbad, CA, USA) according to the manufacturer's protocol. Total RNA samples (with $\mathrm{A}_{260} / \mathrm{A}_{280}$ ratios between 1.8 and 2.0) were quantified spectrophotometrically by absorbance at $260 \mathrm{~nm}$. Less than $2 \mu \mathrm{g}$ total RNA was used to generate cDNA using a reverse transcription kit (TaKaRa, Dalian, China).

The complete CDS of human STC1 mRNA (NM_003155.2) was amplified using the following primers: sense, 5' -ATC AAG CTT ATG CTC CAA AAC TCA G-3'; antisense, 5'-ATG GAT CCT TAT GCA CTC TCA TGG-3' (HindIII and BamH I cleavage sites are underlined). Amplicons were subjected to $1 \%$ agarose gel electrophoresis, purified using a DNA gel extraction kit (Axygen, Union City, CA, USA), and cloned into a pMD-18T TA-clone vector (TaKaRa) for sequencing and subsequent digestion by restriction endonucleases. The gene fragments of interest were then subcloned into the pIRES2-EGFP vector (Invitrogen) using T4 DNA ligase (TaKaRa). DNA sequencing was performed with an ABI Prism 310 genetic analyzer (Applied Biosystems, Foster, CA, USA). The recombinant plasmid was named pIRES-STC1. Endotoxin-free plasmid DNA was prepared from overnight cultures of E. coli DH5 $\alpha$ (Invitrogen) containing pIRES-STC1 using the EZNA plasmid max kit (Omega, Doraville, GA, USA).

\subsection{Design and Synthesis of siRNA}

Small interfering RNA oligonucleotide duplex targeting human STC1 (siRNASTC) was designed and synthesized by Ribobio Biotech Co., Ltd. (Guangzhou, China) as follows: $5^{\prime}$-AUU CGG AGG UGC UCC ACU UdT dT-3' (sense) and 5'-AAG UGG AGC ACC UCC GAA UdT dT-3' (antisense). A functional non-coding siRNA (scrambled siRNA) and a siRNA targeting $\beta$-actin (siRNA actin, data not shown) were used as controls. The sequences of scrambled siRNA and siRNA ${ }_{\text {actin }}$ are proprietary knowledge of Ribobio Biotech.

\subsection{Transfection and Treatments of Caco2 Cells}

Caco2 cells were seeded in six-well plates $\left(2 \times 10^{5}\right.$ cells/well $)$ and incubated overnight in complete IMDM medium without antibiotics prior to transfection. Cells were transfected with pIRES-STC1 $(4.0 \mu \mathrm{g} /$ well $)$ or equivalent amount of pIRES2-EGFP, and siRNA STC1 $_{\text {(100 }} \mathrm{pmol} /$ well) or equivalent amount of scrambled siRNA, and the best volume ratio of pIRES-STC1 $(1.0 \mu \mathrm{g} /$ well $)$ and siRNA STC1 $_{1}$ (100 pmol/well) co-transfected into Caco2 cells using Lipofectamine 2000 (Invitrogen) according to the manufacturer's protocol. Total RNA and protein were then harvested after $48 \mathrm{~h}$.

To further investigate the role of STC1, Caco2 cells were first transfected with siRNASTC1 for $48 \mathrm{~h}$ followed by administration of rhSTC1 protein $(100 \mathrm{ng} / \mathrm{mL}$ dissolved in Hanks' balanced salt solution, ProSpec, Rehovot, Israel, HOR-259) for $4 \mathrm{~h}$. Total RNA and total protein were then harvested. The dose of rhSTC1was chosen based on published report by Madsen et al., who demonstrated that the minimum intestinal net $\mathrm{Ca}^{2+}$ absorption and maximum conductance occurred with the addition of $100 \mathrm{ng} / \mathrm{mL}$ rhSTC1 [17].

\subsection{Real-Time PCR}

Total RNA extraction and cDNA library preparation were performed for each sample as described above. Gene expression was measured by real-time PCR using an ABI StepOne ${ }^{\mathrm{TM}}$ Real-Time PCR System (Applied Biosystems). Reactions consisted of $1 \times$ SYBR Green I (TaKaRa), $0.2 \mu \mathrm{M}$ forward, reverse primers (Sangon, Shanghai, China) for each gene (Table 1), and 1/50 of total reaction volume of ROX. GAPDH was used as an internal control. After denaturation at $94{ }^{\circ} \mathrm{C}$ for $5 \mathrm{~min}$, the reaction proceeded for 40 cycles of $94{ }^{\circ} \mathrm{C}$ for $15 \mathrm{~s}, 60^{\circ} \mathrm{C}$ for $15 \mathrm{~s}$ and $72{ }^{\circ} \mathrm{C}$ for $25 \mathrm{~s}$. A final 5-min extension step at $72{ }^{\circ} \mathrm{C}$ was performed. 
Table 1. Real-time primer sequences utilized in this study.

\begin{tabular}{ccccc}
\hline Gene & $\begin{array}{c}\text { Genebank } \\
\text { Accession No. }\end{array}$ & Primer $\left(5^{\prime}-\mathbf{3}^{\prime}\right)$ & $\begin{array}{c}\text { Product Length } \\
(\mathbf{b p})\end{array}$ & $\begin{array}{c}\text { Annealing } \\
\text { Temperature }\left({ }^{\circ} \mathbf{C}\right)\end{array}$ \\
\hline TRPV6 & NM_018646 & $\begin{array}{c}\text { GGACAACACCCTCTTACAGCA(sense) } \\
\text { CCAGCACCATGAAGGCATA(anti-sense) }\end{array}$ & 224 & 60 \\
\hline TRPV5 & NM_019841.4 & $\begin{array}{c}\text { TCTTAGGCAACTTCTACTGGACTG(sense) } \\
\text { ACGCACCAGGTTCACATTCT(anti-sense) }\end{array}$ & 223 & 60 \\
\hline PMCA1 & NM_001001323 & $\begin{array}{c}\text { CAGCAGGAGAACCAGAACCA(sense) } \\
\text { CAGTGACCATCCGCACAGTAA(anti-sense) }\end{array}$ & 159 & 60 \\
\hline NCX1 & XM_005264514.1 & $\begin{array}{c}\text { TGTGCATCTCAGCAATGTCA(sense) } \\
\text { TTCCTCGAGCTCCAGATGTT(anti-sense) }\end{array}$ & 230 & 60 \\
\hline GAPDH & NM_000376 & $\begin{array}{c}\text { GTGGACATCGGCATGATGAAG(sense) } \\
\text { GGTCGTAGGTCTTATGGTGGG(anti-sense) }\end{array}$ & 181 & 60 \\
\hline
\end{tabular}

\subsection{Western Blotting}

Cells were lysed for $10 \mathrm{~min}$ in ice-cold lysis buffer (50 mM Tris- $\mathrm{HCl}(\mathrm{pH} 7.4), 150 \mathrm{mM} \mathrm{NaCl}$, $1 \%$ Triton X-100, 1\% SDS, $2 \mathrm{mM}$ EDTA, 3\% Nonidet P-40, $2 \mathrm{mM}$ orthovanadate, $50 \mathrm{mM} \mathrm{NaF}$, $10 \mathrm{mM} \mathrm{NaPPi}$, and $10 \mathrm{mg} / \mathrm{mL}$ each of aprotinin and leupeptin) supplemented with $1 \mathrm{mM}$ PMSF (Beyotime, Wuxi, China). The samples were centrifuged at $14,000 \times g$ for $15 \mathrm{~min}$, and supernatants were collected. Total protein concentration was measured with a BCA Kit (Beyotime) following the manufacturer's protocol. A total of $30 \mu \mathrm{g}$ of protein from each sample was subjected to electrophoresis on $12 \%$ SDS/PAGE and transferred to a $0.22-\mu \mathrm{m}$ PVDF membrane (Millipore, Bedford, MA, USA) that was pre-treated with methanol for $2 \mathrm{~h}$ before transfer. The membranes were blocked overnight in $5 \%$ $(w / v)$ skim milk in TBST (0.01 M Tris- $\mathrm{HCl}(\mathrm{pH} 7.5), 0.15 \mathrm{M} \mathrm{NaCl}, 0.5 \%$ Tween-20). Immunoblotting was conducted using diluted rabbit polyclonal antibodies against STC1 (1:1000, Abcam, Cambridge, MA, USA), TRPV6 (1:200, ABclonal, Woburn, MA, USA), TRPV5 (1:600, ABclonal), NCX1 (SLC8A1, 1:400, ABclonal) and VDR (1:1000, ABclonal), mouse monoclonal antibodies against PMCA1b (ATP2B1, 1:300, Abgent, San Diego, CA, USA), and GAPDH (1:5000, Cowin, Beijing, China) as an internal control. Goat antibodies against mouse or rabbit IgG-HPR (1:8000, Cowin) were used as secondary antibodies. The blots were visualized using enhanced chemiluminescence (Cowin).

\subsection{Statistical Analysis}

Statistical analyses were conducted using a one-way ANOVA for each triplicate or quadruplicate sample set of data using SPSS version 17.0 (SPSS, SPSS Inc., Chicago, IL, USA). Values for all parameters are expressed as the mean \pm SEM. A $p$ value $<0.05$ was considered statistically significant.

\section{Conclusions}

In summary, the present work examined the hypothesis that STC1 inhibits $\mathrm{Ca}^{2+}$ transcellular transport in intestinal absorptive epithelia by blocking the influx of $\mathrm{Ca}^{2+}$ into the cells through down-regulation of TRPV6 and TRPV5. Our findings imply that the mechanisms involved in STC-induced inhibition of $\mathrm{Ca}^{2+}$ transport processes may be similar in both fish and mammals. Indeed, our study is the first to show the direct effects of STC1 on mammalian intestinal epithelial calcium-transport proteins, and we hope that these findings enhance the recognition of the roles played by STC1 in mammals. Additionally, the possibility that STC1 influences cytosolic diffusion processes and the molecular mechanisms including calbindin- $\mathrm{D}_{28 \mathrm{~K}}$ and $-\mathrm{D}_{9 \mathrm{~K}}$ should not be ignored because they are also tightly controlled by various calciotropic hormones [2]. Future research should aim to resolve these questions. 
Acknowledgments: Our work was supported by the National Natural Sciences Foundation of China (No. 31172374 and No. 31502132). The funders had no role in study design, data collection and analysis, decision to publish, or preparation of the manuscript.

Author Contributions: Jinmei Xiang, Rui Guo, Chunyun Wan and Dingzong Guo conceived and designed the experiments; Jinmei Xiang, Rui Guo, Chunyun Wan and Liming Wu performed the experiments; Jinmei Xiang, Liming Wu and Shijin Yang analyzed the data; Liming Wu and Shijin Yang contributed regents/materials/analysis tools; Jinmei Xiang, Rui Guo and Chunyun Wan wrote the paper.

Conflicts of Interest: The authors declare no conflict of interest.

\section{References}

1. Hoenderop, J.G.; Nilius, B.; Bindels, R.J. Calcium absorption across epithelia. Physiol. Rev. 2005, 85, $373-422$. [CrossRef] [PubMed]

2. Khanal, R.C.; Nemere, I. Regulation of intestinal calcium transport. Annu. Rev. Nutr. 2008, 28, $179-196$. [CrossRef] [PubMed]

3. Ko, S.-H.; Choi, K.-C.; Oh, G.T.; Jeung, E.-B. Effect of dietary calcium and 1,25- $(\mathrm{OH})_{2} \mathrm{D}_{3}$ on the expression of calcium transport genes in calbindin- $\mathrm{D}_{9 \mathrm{k}}$ and- $\mathrm{D}_{28 \mathrm{k}}$ double knockout mice. Biochem. Biophys. Res. Commun. 2009, 379, 227-232. [CrossRef] [PubMed]

4. Choi, K.; An, B.; Yang, H.; Jeung, E. Regulation and molecular mechanisms of calcium transport genes: Do they play a role in calcium transport in the uterine endometrium. J. Physiol. Pharmacol. 2011, 62, 499-504. [PubMed]

5. Johnson, J.A.; Grande, J.P.; Roche, P.C.; Sweeney, W.; Avner, E.; Kumar, R. 1 alpha, 25-dihydroxyvitamin D receptor ontogenesis in fetal renal development. Am. J. Physiol. Ren. Physiol. 1995, 269, F419-F428.

6. Den Dekker, E.; Hoenderop, J.G.; Nilius, B.; Bindels, R.J. The epithelial calcium channels, TRPV5 \& TRPV6: From identification towards regulation. Cell Calcium 2003, 33, 497-507. [PubMed]

7. Kip, S.N.; Gray, N.W.; Burette, A.; Canbay, A.; Weinberg, R.J.; Strehler, E.E. Changes in the expression of plasma membrane calcium extrusion systems during the maturation of hippocampal neurons. Hippocampus 2006, 16, 20-34. [CrossRef] [PubMed]

8. Rourke, K.; Coe, S.; Kohn, C.; Rosol, T.; Mendoza, F.; Toribio, R. Cloning, comparative sequence analysis and mRNA expression of calcium-transporting genes in horses. Gen. Comp. Endocrinol. 2010, 167, 6-10. [CrossRef] [PubMed]

9. Wagner, G.F.; Dimattia, G.E. The stanniocalcin family of proteins. J. Exp. Zool. A Ecol. Genet. Physiol. 2006, 305, 769-780. [CrossRef] [PubMed]

10. Liu, D.Y.; Yang, S.J.; Wu, L.M.; Xi, Z.-F.; Chen, S.; Dong, S.-Q.; Wang, J.-L.; Guo, D.-Z. Expression and localization of Stanniocalcin 1 in bovine osteoblasts. Pak. Vet. J. 2012, 32, 242-246.

11. Yoshiko, Y.; Aubin, J.E. Stanniocalcin 1 as a pleiotropic factor in mammals. Peptides 2004, 25, 1663-1669. [CrossRef] [PubMed]

12. Tremblay, G.; Delbecchi, L.; Loiselle, M.C.; Ster, C.; Wagner, G.F.; Talbot, B.G.; Lacasse, P. Serum levels of stanniocalcin-1 in Holstein heifers and cows. Domest. Anim. Endocrinol. 2009, 36, 105-109. [CrossRef] [PubMed]

13. Olsen, H.S.; Cepeda, M.A.; Zhang, Q.Q.; Rosen, C.A.; Vozzolo, B.L. Human stanniocalcin: A possible hormonal regulator of mineral metabolism. Proc. Natl. Acad. Sci. USA 1996, 93, 1792-1796. [CrossRef] [PubMed]

14. Yeung, B.; Law, A.; Wong, C.K. Evolution and roles of stanniocalcin. Mol. Cell. Endocrinol. 2012, 349, $272-280$. [CrossRef] [PubMed]

15. Wagner, G.F.; de Niu, P.; Jaworski, E.; Radman, D.; Chiarot, C. Development of a dose-response bioassay for stanniocalcin in fish. Mol. Cell. Endocrinol. 1997, 128, 19-28. [CrossRef]

16. De Niu, P.; Radman, D.P.; Jaworski, E.M.; Deol, H.; Gentz, R.; Su, J.; Olsen, H.S.; Wagner, G.F. Development of a human stanniocalcin radioimmunoassay: Serum and tissue hormone levels and pharmacokinetics in the rat. Mol. Cell. Endocrinol. 2000, 162, 131-144. [CrossRef]

17. Madsen, K.L.; Tavernini, M.M.; Yachimec, C.; Mendrick, D.L.; Alfonso, P.J.; Buergin, M.; Olsen, H.S.; Antonaccio, M.J.; Thomson, A.B.R.; Fedorak, R.N. Stanniocalcin: A novel protein regulating calcium and phosphate transport across mammalian intestine. Am. J. Physiol. 1998, 274, G96-G102. [PubMed] 
18. Wagner, G.F.; Vozzolo, B.L.; Jaworski, E.; Haddad, M.; Kline, R.L.; Olsen, H.S.; Rosen, C.A.; Davidson, M.B.; Renfro, J.L. Human stanniocalcin inhibits renal phosphate excretion in the rat. J. Bone Miner. Res. 1997, 12, 165-171. [CrossRef] [PubMed]

19. Chantret, I.; Barbat, A.; Dussaulx, E.; Brattain, M.G.; Zweibaum, A. Epithelial polarity, villin expression, and enterocytic differentiation of cultured human colon carcinoma cells: A survey of twenty cell lines. Cancer Res. 1988, 48, 1936-1942. [PubMed]

20. Tseng, D.Y.; Chou, M.Y.; Tseng, Y.C.; Hsiao, C.-D.; Huang, C.-J.; Kaneko, T.; Hwang, P.-P. Effects of stanniocalcin 1 on calcium uptake in zebrafish (Danio rerio) embryo. Am. J. Physiol. Regul. Integr. Comp. Physiol. 2009, 296, R549-R557. [CrossRef] [PubMed]

21. Sheikh-Hamad, D.; Bick, R.; Wu, G.Y.; Christensen, B.M.; Razeghi, P.; Poindexter, B.; Taegtmeyer, H.; Wamsley, A.; Padda, R.; Entman, M. Stanniocalcin-1 is a naturally occurring L-channel inhibitor in cardiomyocytes: Relevance to human heart failure. Am. J. Physiol. Heart Circ. Physiol. 2003, 285, H442-H448. [CrossRef] [PubMed]

22. Verbost, P.M.; Flik, G.; Fenwick, J.C.; Greco, A.-M.; Pang, P.K.T.; Bonga, S.E.W. Branchial calcium uptake: Possible mechanisms of control by stanniocalcin. Fish Physiol. Biochem. 1993, 11, 205-215. [CrossRef] [PubMed]

23. Bindels, R.; Ramakers, P.; Dempster, J.; Hartog, A.; van Os, C. Role of $\mathrm{Na}^{+} / \mathrm{Ca}^{2+}$ exchange in transcellular $\mathrm{Ca}^{2+}$ transport across primary cultures of rabbit kidney collecting system. Pflügers Arch. 1992, 420, 566-572. [CrossRef] [PubMed]

24. Hung, N.T.; Yamamoto, H.; Takei, Y.; Masuda, M.; Otani, A.; Kozai, M.; Ikeda, S.; Nakahashi, O.; Tanaka, S.; Taketani, Y.; et al. Up-regulation of stanniocalcin 1 expression by 1,25-dihydroxy vitamin $\mathrm{D}_{3}$ and parathyroid hormone in renal proximal tubular cells. J. Clin. Biochem. Nutr. 2012, 50, 227-233. [CrossRef] [PubMed]

(C) 2016 by the authors; licensee MDPI, Basel, Switzerland. This article is an open access article distributed under the terms and conditions of the Creative Commons Attribution (CC-BY) license (http://creativecommons.org/licenses/by/4.0/). 